University of Nebraska - Lincoln

DigitalCommons@University of Nebraska - Lincoln

Faculty Publications: Department of Teaching, Department of Teaching, Learning and Teacher Learning and Teacher Education

Education

January 2005

\title{
The flight from experience to representation: Seeing relational complexity in teacher education
}

Margaret A. Macintyre Latta

University of Nebraska-Lincoln, Margaret.Macintyre.Latta@ubc.ca

James C. Field

University of Calgary

Follow this and additional works at: https://digitalcommons.unl.edu/teachlearnfacpub

Part of the Teacher Education and Professional Development Commons

Macintyre Latta, Margaret A. and Field, James C., "The flight from experience to representation: Seeing relational complexity in teacher education" (2005). Faculty Publications: Department of Teaching, Learning and Teacher Education. 10.

https://digitalcommons.unl.edu/teachlearnfacpub/10

This Article is brought to you for free and open access by the Department of Teaching, Learning and Teacher Education at DigitalCommons@University of Nebraska - Lincoln. It has been accepted for inclusion in Faculty Publications: Department of Teaching, Learning and Teacher Education by an authorized administrator of DigitalCommons@University of Nebraska - Lincoln. 


\begin{tabular}{l}
\hline TEACHING \\
ANDTEACHER \\
EDUCATION \\
\hline
\end{tabular}

www.elsevier.com/locate/tate

Teaching and Teacher Education 21 (2005) 649-660

\title{
The flight from experience to representation: Seeing relational complexity in teacher education
}

\author{
Margaret Macintyre Latta ${ }^{\mathrm{a}, *}$, James C. Field ${ }^{\mathrm{b}}$ \\ ${ }^{a}$ College of Education \& Human Sciences, University of Nebraska-Lincoln, 118 Henzlik Hall, Lincoln, NE 68588-0355, USA \\ ${ }^{b}$ University of Calgary, Canada
}

Received in revised form 7 April 2004

\begin{abstract}
Gaining access to the inherent relational complexity of teaching/learning situations is essential to learning to teach. As teacher educators our work with prospective teachers indicates that opportunities to develop the capacity for relational knowing are increasingly being denied and dismissed. Specifically, we are concerned with what we perceive to be a flight from the experience of relational complexities, demanding constant discernment in the concrete situated dimensions of teaching and learning, into representative certainty and singularity in ways of seeing,thinking, and doing in classrooms. This paper documents this concern and explores the consequences of such disregard.
\end{abstract}

(C) 2005 Elsevier Ltd. All rights reserved.

Keywords: Teacher education; Learning to teach; School experiences; Relational complexity

\section{Introduction}

What does it mean to learn to teach? What webs of significance do teachers and learners both spin and find themselves suspended in? What do these webs make possible and impossible in terms of practices and understandings? What do teachers and learners become and not become as a result of how we think and act in classrooms? These questions arise out of the relational complexities of classroom life and consider the ways in which

corresponding author. Tel.: + 1401 472-9958.

E-mail address: mlatta2@unl.edu (M. M. Latta). social, historical, cultural, and political dynamics impact the experience of learning to teach. These questions live in the space between self and other-between teacher and context, between teacher and students, between students and context, between students and subject matter, between teacher and subject matter, between students and students, and so on. This paper builds a case, insisting alongside others (e.g.. Cochran-Smith, 2001: Dewey, 1904; Gallego, Hollingsworth, \& Whitenack, 2001; Grundy,19S9; Raider-Roth, 2002), that gaining access to this relational complexity is integral to learning to teach. Gallego et al. conclude, "without opportunities to develop

ISSN 0742-051X

(C) 2005 Elsevier Ltd. All rights reserved.

doi:10.1016/j.tate.2005.05.004 
the capacity for relational knowing, teachers and teacher educators will never be able to teach their students to develop such capacities" (p. 261). We fear such opportunities are increasingly being denied and dismissed in the experiences of prospective teachers. And, we further fear the consequences of such disregard.

Specifically, we are concerned with what we perceive to be a flight from the experience of relational complexities, demanding constant discernment in the concrete, situated dimensions of teaching and learning, into representative certainty and singularity in ways of seeing, thinking and doing in classrooms. Grundy (1989) captures for us the subtle, yet powerful effect that representation, in the form of universally endorsed instrumentalism, is having on teacher education:

If practice cannot provide the certitude that is demanded, then action must be reduced to work, judgment to skill and deliberation replaced by rule following. Thus more and more, rather than education being regarded as an ongoing human 'Good', we hear the education process described as a system which produces 'products', (p. 85)

While acknowledging that the penchant for instrumental modes of teaching that Grundy alludes to is not particularly new, as of late, this form of "standardized fabrication", marketed as a way to achieve a purer, more easily replicated production and form (in "standards" for "quality control") and consumption (in vocational portability) has become consumptive itself-appropriating all other forms of knowledge and human action into a single standardized way of being. The effect of this is massive: all things, including teaching, learning, and curriculum, are challenged to reveal themselves only as forms of something already regulated and secured for unencumbered exchange and consumption (e.g., Zeimelman, Daniels, \& Hyde, 1998). This is what Heidegger (1977) called "enframing", the totalizing way of life at the heart of technology in the contemporary age. The appearance (everywhere it seems) of these enframing initiatives designed precisely to legislate and control responsive human behavior, to determine the end before anything has begun, has strengthened our resolve that if the life and vitality of curriculum is to have a chance in education, things will have to be otherwise.

To be fair, such instrumental modes of action have provided us with a host of benefits, the most fundamental of which are probably evident as strategies, interventions, models, skills, and techniques, creating a repertoire of teaching/learning practices. We can all see the necessity of these in education, and in particular, in learning to teach. Little good comes, it seems, from approaching practice as a form of radical temporality, in which everything depends upon the "instant", forcing our students "into the most erratic decisionism, compelled to lurch from decision to decision with no idea of what they are doing or why or what to do next" (Caputo, 2000, p. 174). On the other hand, we think we have failed, in education, to fully understand the import of what instrumental modes also provide education with-"a fast way out the back door of the flux [of collective life]" (Caputo, 1987, p. 1). The threat that this poses to the ethical realm of teaching and learning, to the possibility of genuine concerted action, to the development of self-understanding, to the development of contextually sensitive teaching/learning practices has, in our opinion, been vastly underestimated.

\section{Seeing relational complexity}

We argue "a fast way out the back door of the flux"(Caputo, 1987, p. 1) is the flight in teacher education from experience to representation. Alexander (1998) talks of such a flight as the "alienation of the senses" affecting the way we feel and live in the world (p.12). He turns to Dewey's (1934) words to clarify:

We see without feeling; we hear, but only a second-hand report... We touch, but the contact remains tangential because it does not fuse with qualities of senses that go below the surface, (p. 21)

Such alienating of the senses limits what we find prospective teachers attending to. Dewey (1904) one hundred years ago drew a distinction between 
"inner" and "external" attention illustrating this alienation (pp. 13,14). Inner attention is manifested through the complexity of relationships found between students, teacher, and subject matter. A teacher searches for ways to draw students into the depth and complexity of subject matter via these relationships. External attention is manifested "in certain conventional postures and physical attitudes rather than in the movement of thought" (p. 14). Dewey describes how student teachers placed prematurely into the role of teacher focus on external rather than inner concerns. Dewey's (1934) further distinction between seeing and recognition begins to account for the consequences:

To see, to perceive, is more than to recognize. It does not identify something present in terms of a past disconnected from it. The past is carried into the present so as to expand and deepen the content of the latter. There is illustrated the translation of bare continuity of external time into the vital order and organization of experience. Identification nods and passes on... The extent to which the process of living in any day or hours is reduced to labeling situations.. .marks the cessation of a life that is a conscious experience. Continuities realized in an individual, discrete, form are the essence of the latter, (p. 24)

In other words, recognition is about labeling and categorizing, but seeing entails receptivity, assuming a commitment to finding out about the ensuing interactions. Dewey's talk of purpose characterized as an attitude rather than a specific goal or aim clarifies the intents of this distinction:

The essential point is that the purpose grow and take shape through the process of social intelligence, (p. 83)

Connectedness is discussed as the organizational thread (p. 90), thus Dewey claims:

We have no choice but to operate in accord with the pattern it (experience) provides or else to neglect the place of intelligence in the development and control of a living and moving experience, (p. 88)
Dewey assumes a seer - adapting, building, and changing meaning in an ongoing conversation between self and other. The implied unity and movement are critical to understanding Dewey's (1938) notion of experience as a moving force (p. 31). He clarifies:

In such experiences, every successive part flows freely, without seam and without unfilled blanks, into what ensues. At he same time there is not sacrifice of the self-identity of the parts... In an experience, flow is from something to something. As one part leads into another and as one part carries on what went before, each gains distinctiveness in itself. The enduring whole is diversified by successive phases that are emphases of its varied colors, (p. 45)

Seemingly, experience entails seeing relational complexities gathering at any moment, concomitantly seeing the significances and potential they hold toward forwarding learning. And, Dewey (1904) is adamant that this movement must be known before it can be directed (p. 21) which is reiterated in Gallego's et al. (2001) plea for accessing relational complexities in learning to teach. Access is via Dewey's (1938) insistence that within experience lives a wholeness that must not be simplified. The vital temporality within experience connecting past, present, and future, portrays people living both in (interaction) and through an environment (continuity). "Different situations succeed one another, but because of the principle of continuity something is carried over from the earlier to the later one" (p. 44). The conceptions of situation and interaction are inseparable. "An experience is always what it is because of a transaction taking place between an individual and what, at the time, constitutes his (sic) environment" (p. 41). The two principles of continuity and interaction intercept and unite (p. 42). Dewey(1934) emphasizes thatexperiencecomesto be "what it is because of the entire pattern to which it contributes and which it is absorbed" ( $p$. 295). Thus experience involves participants actively structuring what is encountered through active undergoing with an open, vulnerable, receptive attitude and doing typified as responding, organizing, and discerning. Dewey (1934) explains 
that the interplay between undergoing and doing is always evolving with beginnings and endings occurring throughout, thus an experience has pattern and structure, because it is not just doing and undergoing in alteration, but consists of them in relationship.Dewey(1934) claims such interplay necessitates seeing versus recognition. Yet, the absence of experience fostering seeing in teacher education denoted by Dewey (1904), persists today with Korthagen (2001) and Gallego et al. (2001), among others, indicating that such absence of experience is the reality of learning to teach currently. And, as Alexander (1998) points out, "the tragedy of the human condition is that we have accepted a maimed version of experience" (p. 12) and thus seeing.

\section{Maimed interpretations of seeing teaching/ learning}

Perhaps the role and place of seeing relational complexities as the source of the movement of learning is what has been repeatedly misinterpreted and misunderstood, betraying experience as a moving force. Dewey (1929), in fact, claims this stating that it is the model of spectatorship that is problematic, thinking of seeing after the model of a spectator viewing a finished picture rather than after the artist producing the picture. Indeed, the impetus for this paper grows out of extended conversations we had with 20 student teachers revealing just this tension. ${ }^{1}$ Teacher preparation coursework taken up by participating students pursued Dewey (1938) experience as a catalyst for furthering questioning and deliberation, not as a thing, but as a process of transformation, pressing

\footnotetext{
${ }^{1}$ The data included throughout the paper are representative of dominant themes resulting from a yearlong research project alongside 20 students in teacher preparation methods courses and throughout student teaching experiences in two research sites focusing on the elucidation of theory/practice relationships in learning to teach. Data collection included regular taped interviews, written responses to casework taken up in the methods courses, and field journal entries by student teachers documenting their practicum experiences, the researchers' observations of learning to teach out in schools and throughout the coursework, and the research literature situating the inquiry and the traditions inherited and being reconstructed.
}

into new ways of seeing and being in the world. But, in practicum situations, experience was apt to be thwarted with seeing considered to be what Kessels and Korthagen (1996) term "disturbances" rather than "central" to the experience of learning to teach (p. 21). We surmise that this tension was heightened through the theory/practice intents of their teacher education coursework positioning student teachers to thoughtfully consider the nature of learners, learning, teachers, and teaching from multiple perspectives. So, we were interested in the contours of these student's experiences of learning to see in teaching/learning situations - what struck them as significant, and in the course of exploring that question, what they were invested in, what they had to undergo and what questions they had about becoming teachers. A case study approach (Creswell, 2002) at two levels was employed. First, in order to gain some understanding of each participant's seeing in classrooms we gathered and analyzed data from each individual's site. Second, in order to discern the terms of seeing, a cross-case and group analysis was conducted. A reflexive approach to data analysis was considered essential operating both inductively and deductively throughout (Alvesson \& Skoldberg, 2000), providing a means to address the interface between the empirical data collected and its interpretations. As the data were collected, we read it for patterns and dimensions. From these readings, questions, directions, and insights emerged. This ongoing reflexive analysis, consisting of careful reading and listening guided by the research aims, served to focus the semi-structured interviews and the learning artifact/document collection. Inductively, data-based themes were incorporated and deductively, literature-based themes were incorporated. Data analysis took place in three phases. Phase I focused on the individual cases, responsive to the emergent features of each setting, thematically blocking and labeling all data to ascertain similarities and differences for learners, learning, teachers, and teaching as seen through the perspectives of student teachers. Phase II entailed a cross-case analysis identifying themes common to all cases and also significant differences. Phase III entailed a group analysis of data focused on finding an 
organizing framework thus directly addressing the major aims of the study to gain insights into the role and place of seeing in learning to teach.

The group analysis surfaced three dominant themes of maimed interpretations of seeing. Three student teachers' accounts, Cara, Nathan, and Sharon, were selected to gain insights into these themes. We urge the reader in attending to the following themes to read beyond the concrete specifics of each student teacher's account, considering what each orients teaching/learning toward, away from, what is seen and not seen, and the costs of "accepting" a maimed version of experience in learning to teach.

\subsection{The rush to "application": Learning to see as a mode of performance}

One of the dominant notions in teacher education is that students are active agents in the constitution of their own learning. Fundamentally, we think that is true. However, when that is simply taken to mean that teachers "learn best by doing", especially if that doing is enframed by instrumentalism, the effect can be that the teacher and student focus their seeing on the wrong thing - the efficiency of their behavior, and in the wrong direction-toward the completion of a fully anticipated response. Cara, a prospective high school science teacher elaborates:

The pressure was to teach. You have to. What does it entail when they say, "Okay, go in there and teach?”... What I think my partner teacher expected was that I would walk into her classroom, look at the curriculum, and know what the students ought to be doing. I would then have lesson plans ready to go. I think she really wanted to see this kind of initiative. But, I kind of felt like I did not know. How should I? I was looking for guidance and she was looking for performance. (Interview 6/6/00)

The assumption that someone could be prepared to "go in there and teach", without concrete understanding of the circumstances, rests upon the belief that knowledge and curriculum exist in forms wholly divorced from time, place and people, that they are self-contained entities, and that they can be captured and represented in prespecified "outcomes", "competencies" and "indicators". Expecting the student to have "lesson plans ready to go" prior to coming to know the situation, the dynamic exchanges that occur in situ, and the traces of prior engagement with the topic, forces the student teacher into an instrumental mode of operation, with a primary focus on what Dewey (1904) refers to as "securing immediate proficiency in teaching" (p. 16).

What happens, in the glare of an instrumental gaze is not surprising. Cara writes:

I can't say how unskilled and unprepared for teaching I felt this past few weeks. I was completely and utterly under the control of the curriculum. My own knowledge was so weak that to even consider deviating slightly from the standard program of studies was terrifying (Artifact \#4, 28/2/00).

What gets produced in these circumstances is the worst kind of epistemological and ontological insecurity, one that our student teachers generally try to outrun, as one of our students put it, with a "planning frenzy" trying to confront the complexity and ambiguity in the absence of situated knowledge as Cara explains:

How do I design an assessment that tells whether or not the students understand the concept of a mold? It is nebulous. What is it that I am exactly looking for? How do I mark this? How do I present it to students so that they know what to do? (Artifact \#4, 28/2/00)

Cara considers good questions, but they seem impossible to address if they are seen through abstract design bent on pre specified measurable outcomes. Part of Cara's dilemma appears to be generated by her partner teacher's advice that she base her lessons solely on concept notes, itemized out in list like fashion. But this kind of knowledge does not provide her with the vision or the landscape she needs to make sense of her teaching-hence her question "What do I look for?" Hidden from her view is a living field of work that she can immerse herself in, identify with and develop a feel for. Absent from her thinking is a concrete sense of place. She operates with an 
instrumental vision. What happens in cases like this is all too familiar:

Unfortunately, the thing I dislike is I slid into this lecture style of teaching, which I absolutely hate, but that is exactly what I would end up doing. I thought... you present this lecture and they take down notes and you see faces staring at you; nobody is falling asleep, but nobody is jumping up and down going "ah ha" or asking questions either. I kept it to myself, but I continued to wonder, "How on earth do you tell if they got it? How do you know?" (Interview, 6/6/00)

How would one know indeed? And what is it that her students come to know? The knowledge she is encouraged to see is free of living referents; fixed and fully formed, existing everywhere and nowhere, somehow, amenable to endless repetition without variation. It does not require a learner to be brought into being, and it does not seem to bring learning into being either, deepening senses of wonder, helping participants understand both where and who they are. The instruments of teaching, deployed "efficiently" can produce wellorchestrated student and teacher behavior: precisely hit pre-specified "targets", exquisitely timed transitions and neatly completed tasks. At the same time, they can cut both student and teacher off from a sense of being "corporeally embedded in a living landscape" (Abrams (1996, p. 65).

\section{2. "In her own image" learning to see as imitation}

As teacher educators we ask, how is it possible for student teachers to see where they fit, or to find their place in such circumstances? How do they enter the, field, find the range of their mobility, exercise their powers of judgment, i.e., become someone in particular, somewhere? Nathan, a student teacher in a grade one classroom reveals the problem:

The teacher was basically controlling every movement of the children. I did not know where I fit in. That was disenchanting and unsettling. I did not know what to do. I recall going over to look at some of the children's literature, and my eyes turned away from the teacher and right away she said, "Mr. Richard, what are you doing?" I was quaking in my boots... I think what bothered me the most was the teacher centeredness of the classroom. There was little room for children's questions. And, little room for me to be different from her. The way I will put it was her desire to make me in her own image. She saw her role that way. I wanted to learn from her, so, this was partially okay. But, on the other hand, I wanted to explore the teaching role as well; the way I saw it... There was a very rigid curriculum. It was not like curriculum making. There was some interaction, but it was only around filling in a blank, so to speak. I knew these kids had so much to offer. The result was that the kids learned to be passive... I also felt quite stifled and rigid. I could not interact freely and I had to watch my step all the time. I did not want to break one of the rules... I saw so much potential in this classroom-in the materials and in the skills of the teacher. It just seemed there was a fear of stepping beyond the boundaries of what she was used to... It was all about efficiently pacing students through stuff; let's crank it out, we have a lot to get covered instead of stopping midway and going in a new direction... so many missed opportunities. (Interview, 8/6/00)

Concretely, Nathan is speaking here of missing a chance to see curriculum with his students in a way that allows something new and different to emerge from their interactions. His attempts to see the curriculum differently disturbed the orderliness of the classroom and disrupted the image of teacher. In response to this, generic features of teaching and learning were bracketed out and Nathan was positioned to imitate the teacher subsuming her ways of teaching. He explains that:

Basically, none of the children were allowed to move or speak or anything. It was very tightly controlled. And, if they did they were immediately spoken to... the teacher told me that if I let students ask all these questions, it would take you on all these tangents. Well in my view, some of that was where I wanted to go. And she 
was shutting all that down. And it was in the name of behavior control. That bothered me throughout. The children never really got to ask their questions. (Interview, 8/6/00)

Nathan was aware of a violation between what he was being asked to recognize and what he saw. He attempted to expose this violation inflicted by separating features away from the entirety of his experience. He is aware of binding, dissecting, and preserving, tearing his teaching into unrelated pieces. Nathan explains:

Interaction with students is key to teaching and learning. When I stepped into the classroom I would interact with students. In the process, I would step outside myself as best I could and observe who I was while I was interacting. Did my perceptions of self fit with how others saw me? Was I reaching the child? Was she/he reaching back to me? Was our interaction around subject matter meaningful? But interaction to the teacher meant so much less than I understood to be necessary. It was like one-way communication that was deemed successful if students appeared to be on task. What I attempted to do was interact with the kids and find ways into the subject matter; get to know the kids... the teacher did not understand why at first. I had to start to let the teacher know who I was; what my strengths were and how I saw the classroom and the nature of interaction differently... and, not fear to actually share about that. (Interview, 8/6/00)

As Alexander (1998) points out, Dewey termed such seeing perception involving "an opening outward of the body to the world, an exploratory and intensely receptive activity, and this means a capacity to suffer a vulnerability. To be able to experience the world we must be willing to be wounded by it" (p. 13). Nathan willingly assumed such vulnerability as he attempted to perceive the intimacy of relations complicating the classroom. This attempt surfaces another distinction raised by Dewey (1934) between form and superimposed design (p. 17). Nathan desired and sought lesson forms coming into being through engagement with students and subject matter. His teacher preferred to bracket out generic features of teaching and learning to be applied to a pre-determined learning situation. Such imposed imitative features such as lesson pacing, closure, and management routines regulated what lessons ought to look like in advance. In contrast, Nathan tentatively considered what it was that ought to be done on a continual basis given the specific subject matter, the context, the students, and the particularities that surfaced throughout his lessons.

\subsection{Learning to see as applied theory-desiccated from self and situation}

Participating prospective teachers had spent time theorizing in university coursework about the nature of learning and teaching, collectively reckoning with many possibilities for teaching practices. But such theorizing is quickly desiccated in the concrete realities of some classrooms. Sharon, another student teacher in a junior high art classroom, explains:

I was only seeing one teaching theory or method and I was having huge problems with it. For example, I think the constructs behind art would help students understand art. But, I was told that they are not going to be able to get it. They are too young. But, I do not think that is the case. It is up to me to find a way into that conversation. And I did have several moments when I felt artistic theory did come alive in the classroom conversation. I was glad I just pushed forward with my sense of what might work. It was my own confidence in myself as an artist that gave me enough assurance to risk, though. Reading Dewey and Eisner made me curious about what can be done by a teacher to encourage true learning experiences for students. I wanted to continue to discover the conditions that are necessary. I was pretty sure the students would enjoy new art techniques and the knowledge I could share with them. The teacher kept saying, "You have all this artistic knowledge, but, what about teaching methods? You know about art, but, you do not know about teaching it to kids." And, I am left 
thinking; I do not understand why I do not know that. (Interview, 5/6/00)

Kessels and Korthagen (1996) point out one of the problems of splitting theory and practice. Often abstract teaching theories:

Lack flesh and blood in a very literal sense; they do not have a face, nor a repertoire of actions. They have no temperament, no personal characteristics, no history, no vices, and no virtues. They cannot be seen in action, nor talked to, nor criticized, nor admired. In short, they do not have any perceptual reality; they are just concepts, abstractions. Therefore, they cannot be identified with. (p. 21)

Sharon deliberately set out to "find a way into conversation" with her students about aspects of art theory. But, such thinking was strongly discouraged. Attempts to see theory/practice relationships through continuing to reckon with possibilities for her teaching practice were thwarted. Theory was not understood as occurring within situations, arising out of the purposes and particularities encountered. Instead, theory was understood as an applied approach or method for teaching with theorizing considered to be abstract, impractical ideals that could never constitute one's practice as a teacher. Thus, opportunities to see the simultaneous interplay of theory and practice in concrete situations of teaching and learning were limited. This further curtailed the role of seeing self in learning to teach. Sharon desired and struggled with ways to bring her identity into the classroom. She comments:

I have talked about the nature of art until I am blue in the face. And, I have listened to it, I do not know how many times. But when I was thinking about the nature of art in such a way that I could present it to my students, holy smokes did it make a difference! Like I have read so much art theory and if I get from point A to point B I am done and I just hope the professor does not ask me any questions. But, explaining the nature of art to grade sevens is another thing. They do not have an art vocabulary. How do I begin to get the concept across? I really had to know what I was talking about, so that I could find ways that would make sense. (Interview, 5/6/00)

But Sharon's desires and struggles to bring personal understandings to teaching/learning situations were brushed off as interfering with the task of learning. As she struggled to allow a learning space for individual student understandings she was told it complicated and delayed accomplishment of the learning task. She gathered that inviting questions and discussion from students was a complete waste of time. So, Sharon gathered that her forthcoming attempt to enliven art theory would be futile. The message being relayed was that the particularities of context and subject matter, the character of teaching/learning situations and participants, were not worthy of consideration.

With focus on pre-determined work, skill, and regulated procedures, the inattention to character and genuine action in this classroom provided little, if any, opportunity to see/experience teaching practice in other ways. It is not that there is no need for such norms, but, unless they:

Are informed by the wisdom that enables them to be dissolved in the demands of responsivity to the particularities and immediacy of lived situation, the rules become sterile, scholastic hindrances to compassionate action rather than conduits for its manifestation. (Varela, 1999, p. 74)

\section{Experience versus representation}

The student teachers'accounts convey becoming experienced as being stitched into new sets of reciprocal relationships with the world. Both the pleasure and the difficulty these students encountered revolve around what Abrams (1996) calls "being woven into the present", that is, coming to terms with being inserted into the middle of things, into worlds, at the university and in the schools, already in motion. We found that seeing, fundamentally of what was at stake in a particular situation-of what the partner teacher was attempting to do when she taught, of the interactions between her and her students, of what the students were interested in and knew, of what counted and 
did not count, and finally of where they stood and how they felt about being caught up in the unfolding action around them-to be an essential part of becoming experienced. But, in each case the classroom reality positioned these student teachers to flee from such notions. Thus, the above accounts portray knowledge severed from experience, consequently a teacher's relation to teaching/learning situations embraces the classical distinction of form and matter, subject and object, deliberately deciphering or ordering teaching/ learning situations according to a pre-formulated plan, rather than teaching/learning being about building relations between self, other, and subject matter,livingin-between these entities, negotiating knowing within experience.

In varying degrees Nathan, Cara, and Sharon resisted the flight from experience to representation and began to see a mode of teaching that was radically different from the instrumental sense of the notion. Such seeing entailed deliberatelybringing to their lesson formation a sense of making/ creating that positioned all to partake in the venture. Much intentional planning and preparation under girded their lessons. But, the space to explore this groundwork as a springboard for students to take their learning in multiple directions was curtailed. The space to play with ways teachers might foster and support this movement meaningfully for students was confined. Beckoning to Nathan, Cara, and Sharon were other relevant matters concerning teaching and learning. But what actually counted as relevant matters in these classrooms occluded hope of experiencing such genesis. The necessary mode of seeing inspiring genesis reconsiders know-how and knowwhat to be an interplay of interpretations rather than an exchange of information. In this way students and teacher might continually revise and enlarge understandings. But, such a relational dynamic was more apt to be feared.

Some of the far reaching and pervasive consequences of teacher education programs fleeing from experience to representation surface in the student teachers' accounts: the occlusion of much hope of seeing relational complexities as a catalyst for the movement of learning in self and others, the bracketing out of generic features of experience to represent teaching/learning, the inattention to specific character and genuine actions, and the desiccation of theory and self from the particularities of teaching/learning situations. Thus, Dewey's (1938) choice "to operate in accord with the pattern it (experience) provides or else to neglect the place of intelligence in the development and control of a living experience (p. 88) is confronted. For, it is through the glimpses of student teachers attempting to attend to the relational complexities in their classrooms that we saw moments of student teachers living out Dewey's (1904) interaction of mind to mind. Diane, another young teacher provides a poignant example of such confrontation:

In a kindergarten classroom an architect came to teach students about the nature of his work. As he was speaking, he discussed the importance of the triangle shape because of its strength in construction. I had noticed a student playing with his necklace throughout and I was kind of monitoring him thinking he was not listening. I resisted saying anything to him because I observed that he did not seem to be distracting others and thought he would be provoked to listen soon enough. After the architect talked about triangles I observed the student making numerous triangle shapes with his necklace on the floor in front of him. Perhaps he was listening all along, internalizing the information. (Artifact \#21, 2/20/02)

Through Diane's attentiveness toward this student she begins to see relational complexities and the ensuing movement of thought, and perhaps such seeing will lead Diane to explore ways to encourage, nurture, and sustain the movement of thinking alongside all students.

The consequences of the flight from experience evidence a distinction between representation and being-in-the-world. Csordes (1994) explores this same distinction noting that the difference is methodologically critical. It is this methodological distinction that these prospective teachers met in classrooms:

Representation is fundamentally nominal, and hence we can speak of a representation. 
Being-in-the-world is fundamentally conditional, and hence we must speak of existence and lived experience. (p. 10)

Dewey (1938) takes it up as a way of being in the world that does not separate knowledge from interest, or theory from practice, but insists on a pervasive qualitative whole. His emphasis on the pervasive whole of experience-all parts linked, not succeeding one another, experienced as connected-creates a vital movement that belongs to the self and situation concerned in the movement. The movement is sustained through the "principle of continuity "(p. 27) and the "principle of interaction"(p. 38). It is this relational meeting place of situation and interaction that Nathan, Cara, Sharon, and Diane ventured into, exploring parts within the greater whole. This relational meeting space opens on to a ground that is fragile rather than firm and comes to be "what it is because of the entire pattern to which it contributes and which it is absorbed"(Dewey, 1934, p. 295). This pattern or structure is necessarily mindful of the particularities of individual and situation helping "prospective teachers be in touch, intimately related with the process of actual experience, such that they learn to be open to their experience, to be radically undogmatic, in touch with self, others, and the character of the circumstances in which they find themselves"(Field \& Macintyre Latta, 2001, p. 885). Thus, such ground expects student teachers to actively see, structuring what is encountered on a continual basis. It is Dewey's movement of experience that student teachers glimpsed and felt its absence. Perhaps the meeting place of situation and interaction forms the ground, re-surfacing relational complexities in teaching and learning. For such ground assumes personal investment seeking transformation, demands attention to particularities, relies on collective action acknowledging a reciprocity between self and other, and understands the pervading ethical responsibility of all judgments. This conditional, indeterminate ground is central to being-inthe-world.

Representation, on the other hand, severs the self from the situation. Encouraged to detach themselves from the circumstances in which learning develops, student teachers acquired skills to produce finely orchestrated lesson products that took on a generic face. Student teachers disliked suppressing subjectivity, the lack of felt agency, and vitality. Teaching/learning as representation stripped all pleasure and satisfaction found in moments of transformation and creation.

\section{Conclusion}

We are fearful of the maimed notions of seeing evidenced in student teachers' teaching/learning accounts. Representation reduces the "good" to quantifiable "goods" that are seen to be desirable for all. In fact, it seeks to avoid questions about the good as by reducing action to pre-determined behavior, substituting finite goals for transcendental aspirations and replacing judgment with skill (Dunne, 1997; Grundy, 1989). But, we are also fearful of the ground relational complexity opens on to. But, it is a fear that ought not to be suppressed or dismissed. Rather, it must be respected and valued as opening on to an ethical space, orienting toward the pursuit of a relational good in teaching and learning. Learning experienced as unfolding in classrooms, resisting means and ends, reliant on the act itself, generates meanings within the encounter. Relational complexities recover the importance of self-involvement in teaching/learning situations. Transformed subjectivities emerge through such reciprocal relationships between self and other; a greater belongingness to learning situations results. Contrarily, a distanced self does not grapple with creating teaching/learning situations as encounters between self and other. Student teachers noted a lack of felt purpose and commitment. The lack of self-investment in teaching/learning situations forced them to rely on pre-established expectations with little, if any, sense of investment.

Acting wisely, searching for "an ongoing human good"(Grundy, 1989) ought to matter in teaching/ learning. The maimed interpretations of seeing through student teachers' eyes evidence constraints. As teacher educators we see an urgent need to prepare prospective teachers to see with "prudence", judgment", "deliberation", and 
"interaction" in their practices (Dunne, 1997). The student teachers' accounts provide a reminder of why this is imperative. Regarding the ethical realm of teaching/learning, we wonder alongside participating student teachers, how many students' and teachers' questions are ignored, dismissed, and perhaps not even given a space to form, in order to conform and perform regulated ways of thinking and acting. Orienting teaching/learning toward oneness, consequently turns away from multiplicity. Regarding the possibility of genuine concerted action on the parts of students and teachers, we wonder alongside participants, how many students and teachers distance themselves from their school work choosing to simply go through the motions, play the game, or rather, become ambivalent, rarely, if ever, feeling connected to subject matter, resisting the game. Orienting teaching/learning purposefully toward preconceived representations of learning, following set orders, sequences, and hierarchies resulting in generic products, consequently turns away from fluid, purposeful learning encounters between students and teachers resulting in divergent learning processes and products. Regarding curtailing the development of self-understandings, we wonder alongside participants, how many students and teachers are labeled "unsuccessful" and "disturbances" because they do not see any aspect of themselves in their schoolwork or curricular practices, rarely finding space for their ideas, stripping confidence in themselves as learners and thinkers. We wonder how a set pace and direction limits, overwhelms, and frustrates some students and teachers. Orienting teaching/learning toward prefigured ways of being and doing masks differences, consequently turning away from respecting and valuing differences as catalysts in coming to know self and others. Regarding the development of contextually sensitive curricular practices, we wonder alongside participants, what is missing, what is lost, by ignoring the particularities of individuals and situations in teaching/ learning? We ask what might be gained through seeing particularities as springboards for teaching/ learning? These interrelated wonderings cause us to conclude that relational complexities appear to be feared in teaching/learning. And yet, relational complexities are what generate the movement of thought as we constantly question what we see and think about the world as it opens up. The vitality inherent within relational complexities reorients learning appropriately for learning's sake. And, is this not what ought to be? Recovering relational complexities holds the potential for bringing prudence, judgment, deliberation, and interaction forward as primary to seeing within teaching/ learning situations. Nathan, Cara, Sharon and Diane sought out relational complexities, but we are dangerously close to losing sight of their place and role in teaching and learning.

\section{Acknowledgement}

Funding, in part, for this work was received from The Research Council, University of Nebraska-Lincoln.

\section{References}

Abrams, D. (1996). The spell of the sensuous. New York: Pantheon Books.

Alexander, T. M. (1998). The art of life: Dewey's aesthetics. In L. A. Hickman (Ed.), Dewey: Interpretations for a postmodern generation (pp. 1-22). Bloomington: Indiana University Press.

Alvesson, M., \& Skoldberg, K. (2000). Reflexive methodology. London: Sage Publications.

Cochran-Smith, M. (2001). Constructing outcomes in teacher education: Policy, practice and pitfalls. Education Policy Analysis Archives, 9(11), 1-57.

Caputo, J. D. (1987). Radical hermeneutics: Repetition, deconstruction and the hermeneutic project. Bloomington: Indiana University Press.

Caputo, J. D. (2000). More radical hermeneutics: On not knowing who we are. Bloomington: Indiana University Press.

Creswell, J. W. (2002). Educational research: Planning, conducting, and evaluating quantitative and qualitative research. Upper Saddle River, NJ: Merrill/Prentice-Hall.

Csordes, T. J. (1994). Embodiment and experience. Cambridge: Cambridge University Press.

Dewey, J. (1904). The relation of theory and practice in education. In C. A. McMurry (Ed.), The relation of theory to practice in the education of teachers: The third yearbook of the National Society for the Scientific Study of Education (pp. 9-30). Chicago: University of Chicago Press.

Dewey, J. (1929). The quest for certainty. New York: Perigee Books. 
Dewey, J. (1934). Art as experience. New York: Capricorn Books.

Dewey, J. (1938). Experience and education. New York: Collier Books.

Dunne, J. (1997). Back to the rough ground. Notre Dame: University of Notre Dame Press.

Field, J. C., \& Macintyre Latta, M. (2001). What constitutes becoming experienced in teaching and learning? Teaching and teacher education: An International Journal of Research and Studies, 18(11), 885-895.

Gallego, M. A., Hollingsworth, S., \& Whitenack, D. A. (2001). Relational knowing in the reform of educational cultures. Teachers college record. No. 2, April (pp. 240-266).

Grundy, S. (1989). Beyond professionalism. In W. Carr (Ed.), Quality in teaching: Arguments/or a reflective profession (pp. 79-99). London: Falmer Press.
Heidegger, M. (1977). The question concerning technology and other essays. New York: Harper and Row.

Kessels, J. P. A. M., \& Korthagen, F. A. J. (1996). Linking theory and practice: Changing the pedagogy of teacher education. Educational Researcher, 28(4), 4-17.

Korthagen, F. A. J. (2001). Linking practice and theory: The pedagogy of realistic teacher education. London: Lawrence Erlbaum.

Raider-Roth, M. (2002) Trusting knowledge: Examining the relational complexities of student self-assessment work. A paper presented at the American Educational Research Association, 2002, New Orleans.

Varela, F. J. (1999). Ethical know-how. Stanford: Stanford University Press.

Zeimelman, S., Daniels, H., \& Hyde, A. (1998). Best practices: New standards for teaching and learning in America's schools (2nd ed.). Portsmouth, NH: Heinemann. 